\title{
Extractive Landscapes: The Case of the Jordan Refugee Compact
}

\author{
JULIA MORRIS
}

\section{Abstract}

In a climate of immigration securitization, recent years have seen a global move away from humanitarian resettlement responses in sites of displacement. Instead, wealthy governments in the Global North often finance poorer third countries and rural regions of territories to abet border enforcement. The Jordan Compact, in particular, has been upheld as an economic development model that provides an "innovative alternative" to refugee camps, as well as to protracted refugee situations. Yet, as much research shows, the direct economic gains from this trade concessions scheme have been limited. This raises the question, What value does the Jordan Compact hold with such ample evidence of failure? Importantly, how is this failure experienced by refugees in practice? Drawing on fieldwork conducted in Amman and northern Jordan, this article advances a framework centred on extractivism to better detail how value is extracted from migrants and displaced persons at the expense of their well-being. The article illuminates the disjuncture between the lack of profit achieved directly from the Jordan Compact's trade concessions and the forms of value extracted from refugees' immobility. Overall, I argue that these economic development policies formalize precariousness, allowing the international community to abdicate global responsibility and reap the benefits of a purported altruism.

\section{Résumé}

Dans un climat de sécurisation de l'immigration, on a assisté ces dernières années à un recul des réponses de réinstallation humanitaires axées sur les sites de déplacement. Souvent, les gouvernements riches du Nord global financent plutôt des tiers pays plus pauvres ainsi que des régions et territoires ruraux pour soutenir des projets de renforcement des frontières. Le Pacte pour la Jordanie, en particulier, a été salué comme un modèle de développement économique qui fournit des "alternatives innovantesm» aux camps de réfugiés ainsi qu'aux situations de refuge prolongées. Cependant, comme le démontre beaucoup de recherches, les gains économiques immédiats de ce régime de concessions commerciales ont été limités. Ceci soulève la question suivante: quelle est la valeur accordée au Pacte pour la Jordanie malgré les preuves de son échec? Comment cet échec est-il vécu en pratique par les réfugiés? S’appuyant sur du travail de terrain effectué à Amman et au nord de la Jordanie, cet article met de l'avant un cadre théorique centré sur l'extractivisme pour mieux saisir comment la valeur est extraite
(C) Julia Morris, 2020. This open-access work is licensed under a Creative Commons Attribution-NonCommercial 4.o International Licence, which permits use, reproduction, and distribution in any medium for non-commercial purposes, provided the original authorship is credited and the original publication in Refuge: Canada's Journal on Refugees is cited.
Cette œuvre en libre accès fait l'objet d'une licence Creative Commons AttributionNonCommercial 4.o International License, laquelle autorise l'utilisation, la reproduction et la distribution de l'œuvre sur tout support à des fins non commerciales, pourvu que lauteur ou les auteurs originaux soient mentionnés et que la publication originale dans Refuge: revue canadienne sur les réfugiés soit citée. 
des migrants et des personnes déplacées aux dépens de leur bien-être. L'article met en lumière l'écart entre le manque de bénéfices directement obtenus des concessions commerciales du Pacte pour la Jordanie et les formes de valeur extraites de l'immobilité des réfugiés. Globalement, je soutiens que ces politiques de développement économique formalisent les conditions de la précarité, permettant à la communauté internationale d'abdiquer sa responsabilité globale et de tirer profit d’un prétendu altruisme.

$\mathrm{S}$ ince the Syrian conflict, over six million refugees have been displaced. ${ }^{1}$ As the crisis has continued into protracted stages, wealthy governments in the Global North have moved away from humanitarian resettlement responses towards funding development projects in regions that neighbour the conflict. By financing less-developed countries, European governments in particular are looking to reduce transit migration from those countries and prevent the arrival of migrants across their borders through foreign investment and trade. Meanwhile, major refugee host states in the Global South have leveraged their proximity to sites of mass displacement in order to negotiate self-serving policies. ${ }^{2}$

Jordan holds the third-largest population of registered Syrian refugees in the region at 671,428 people, but second in demographic ratio of Syrians in the country. ${ }^{3}$ Within the wider refugee-development policy trend, the government of Jordan, the European Union (EU), and the World Bank signed the US $\$ 1.7$ billion Jordan Compact in February 2016, a landmark political declaration. The compact was designed to transform the challenges of hosting such a significant number of Syrian refugees into a development opportunity for Jordan, while also improving the livelihoods of both Jordanians and the country's Syrian refugee population. The deal combines humanitarian and development funding with pledges of Us $\$ 700$ million in grants to Jordan annually for three years and concessional loans of $\$ 1.9$ billion. Payment of grants and loans are linked to specific targets. One of these targets is to expand access to the formal labour market for Syrian refugees by issuing 200,000 work permits in specified sectors and support Syrian education through the Accelerating Access to Quality Formal Education plan. The compact also stipulates that Jordan will institute reforms to improve the business and investment environment and formalize Syrian businesses. In exchange, Jordan would be offered considerable financial support and the opening up of tariff-free trade in the European market to Jordanian goods. Unemployment in Jordan stands at 18.2 per cent (around double that for youth) and 14.4 per cent in poverty. ${ }^{4}$ Tying economic incentives directly to work opportunities for refugees attempts to open the job market to Syrians and Jordanians. It is also a means for the Jordanian government to create new economic opportunities by encouraging more international aid to be channelled into the country.

This article considers employment programs focused on Syrian refugees in Jordan, on the basis of my empirical findings in the field. Although refugee employment is significantly promoted by organizations like the World Bank and the EU, behind the headlines, the Jordan Compact has been widely considered a failure. ${ }^{5}$ In non-governmental and state reporting, and in migration studies scholarship, a critical body of literature has been produced on the Jordan Compact in recent years. ${ }^{6}$ In these studies, the work permit process is found to be complex and time-consuming, with many employers continuing to employ refugees without permits. ${ }^{7}$ My findings expand upon this research into the impact of economic policies on migrants' and refugees' subjectivities $^{8}$ and Syrian refugee policies focused on employment in particular. 9 This scholarship offers a critical picture of the merging of humanitarian and economic agendas, looking at the effects of a major policy trend that intersects neoliberal values and refugee policies.

Katharina Lenner and Lewis Turner's research is arguably the pre-eminent academic study of the Jordan Compact. ${ }^{10}$ They show that meaningful social changes have been abandoned for refugees in Jordan in the quest for meeting formal targets of donors and implementing agencies. Their work details how international refugee responses have moved from portraying Syrian refugees as objects of humanitarian care to development opportunities. Yet underneath the mantra of self-reliance, jobs available for refugees tend to be in sectors like garment manufacture, which are unregulated and rife with overtime physical abuse. ${ }^{11}$ The labour rights of migrants can be compromised, resulting in extremely low wages, forced overtime, and forms of exploitation.

Much of this research draws attention to the encroachment of economic agendas into humanitarian contexts. In recent years, market metrics have been brought to the fore by humanitarian workers striving to maintain relevance. ${ }^{12}$ In fact, "transforming the refugee crisis into a development opportunity" is the operational mantra surrounding the Jordan Compact, with Jordan showcased as the poster child of this "win-win" solution. ${ }^{13}$ Yet, as others show, the direct economic gains from the trade concessions scheme have been very limited, and from this standpoint, it should be considered as a disaster. ${ }^{14}$ This questions the value of the Jordan Compact with such an ample evidence of failure. And importantly, how is this failure experienced by refugees in practice?

Building on the work of Kelberer ${ }^{15}$ and Lenner and Turner, ${ }^{16}$ I argue that refugee employment efforts are better understood through a framework centred on extractivism: an analytic I have advanced elsewhere to document 
and critically theorize the expansion of mining sectors into domains of human resources, such as migrants and refugees. ${ }^{17}$ Extractivism is a mode of accumulation, with deep roots in colonial and imperial endeavours, whereby natural resources are removed at a high intensity for export markets. ${ }^{18}$ As a method of colonial appropriation, extractivism has been essential in the industrial development and prosperity of the Global North at the expense of poorer countries, particularly in the Global South. ${ }^{19}$ The exploitation of raw minerals has also enabled wealthy networks of transnational elites, and the domination of corporations and non-governmental organizations to move into ever-growing resource frontiers globally. ${ }^{20}$ Here, capitalist values have encroached into new forms of extractive intrusion that amount to extracting value(s) from humans, whereby countries in the Global South strategically capitalize on the value of refugee hosting and/or containment.

Arguably, one of the major reasons why scholarship has difficulty in capturing the political economic logics of refugee employment programs in Jordan is that it is often reduced to economic interests alone. Capital, of course, takes a variety of forms, including human, financial, symbolic, and moral capital, all of which generate surplus value, and all of which enter into the refugee equation. Migrants and displaced persons have become utilized as forms of capital through containment, ${ }^{21}$ here, under the line of "refugee crisis as development opportunity." The extractivism framework makes clear how value is extracted from refugees, as one lucrative industry sector. Although only 7 per cent of the world's population are refugees, governments around the world, particularly in the Global North, have also gained purchase through the symbolic capital attached to refugees and migrants. ${ }^{22}$ This includes the representation of a spectacle of strict asylum policies, as much as one of humanitarian benevolence. In a climate of immigration control and securitization, poorer third countries such as Jordan, and rural regions of territories, have been financed to abet the project of border outsourcing and externalization..$^{23}$ Such forms of support entail not only direct cash payments, but also economic contributions to fund national security or development interests in exchange for refugee-hosting efforts. Incentives also include the renegotiation of trade agreements, which open Western markets to states in the Global South, and the relaxing of travel restrictions, as has been the case with Morocco and Turkey. ${ }^{24}$ Meanwhile, corporations, non-governmental organizations, interest groups, and academics, among others, also profit as contracts are outsourced for refugee-hosting provisions or opportunities arise for conducting research projects. ${ }^{25}$ These developments have led scholars to refer to an "immigration industrial complex" 26 and an expansive "migration business." 27
Proponents of rentier state theories, on the other hand, argue that economic liberalization discourse is mainly window-dressing, and underneath lie political rationalities of appeasing different constituencies. ${ }^{28}$ Victoria Kelberer has coined the term refugee rentierism to detail how states leverage their position as host states of displaced communities. ${ }^{29}$ Using refugee rights as a strategic instrument of foreign policy, Jordan, as one major host state engaging in refugee rent-seeking behaviour, extracts revenue from other states for maintaining those refugee groups within their borders. This article takes these logics into account, illuminating the disjuncture between the lack of profit achieved directly from the Jordan Compact's trade concessions and the political economic logics of Jordan's rent-seeking strategies. Instead oft focusing on the profoundly political problems that underpin the drivers of forced migration, I argue that the Jordan Compact regulates people's movement while extracting value-laden prerogatives.

These debates are important to consider. International advisors have presented the socioeconomic integration of Syrians in Jordan as a way to support Syrians financially and boost the Jordanian economy overall, while reducing the number of Syrians attempting to reach Europe. Similar models in other host states such as Ethiopia, Lebanon, and Turkey also tie refugees in with financial incentives and the underlying goal of stemming the flow of migrants and refugees to Europe. The high commissioner for refugees, Filippo Grandi, recently announced that the Jordan Compact offers a "new blueprint for supporting refugees." ${ }^{\circ}$ However, as this article will show, the economic development model of the Jordan Compact has not only failed to reinvigorate the Jordanian economy, but it has also not offered Syrians the prospect of a dignified, self-sufficient life. Given that the Jordan Compact was widely endorsed by development and humanitarian actors, it is essential to question some of the assumptions and beliefs that underpin its practice.

This article draws on fieldwork in Jordan and New York during 2018, a period that saw protests in Jordan and the ousting of Prime Minister Hani Al-Mulki. Prior to the protests, I led a week-long field intensive with university students from the New School in March 2018 to examine the implementation of the Jordan Compact. Students interviewed leading humanitarian and development organizations operating in Amman whose work intersects with refugee employment. These interviews were planned and led by students who devised interview questions connected to the project's overall objectives. During the field visit, other opportunities also arose for learning about the context in more depth, including simply speaking with refugees, locals, and aid workers in more informal settings. I returned to Jordan in June 2018 and then February-March 2019 to conduct 
follow-up research as well as facilitating fieldwork trips for the New School students at the International Rescue Committee's office in Amman.

This article starts by presenting the particularities of the Jordanian context, placing the country's newest "trade deal" within past national economic development projects and experiences of hosting refugees. I then turn to examine the characteristics of and challenges faced by employment programs in Jordan, detailing how extractive logics have overtaken refugees' well-being. I close by placing the Jordan Compact within a system of globalized production, in which forms of value circulate outside of Jordan at the expense of refugees' immobility. Overall, I find that these policies formalize precariousness, allowing the international community to abdicate global responsibility and reap the benefits of a purported altruism.

\section{Oil Turned Refugee Economies}

The Jordan Compact is best understood locally within the Hashemite Kingdom's extractive history and economic dependencies. Jordan has long depended on the support of outside powers such as Great Britain, the United States, and oil-rich Arab states for its economic and political wellbeing. ${ }^{31}$ Even after independence in 1946, from its establishment as a British protectorate, Jordan's finances remained guided by the British government. But in the 1950 os and 1970s, Jordan shot up economically as a result of remittances received from migration to neighbouring oil-rich countries. Jordanian workers flocked to Gulf states to work the oil fields as skilled laborers and in professional positions such as engineers, bankers, and teachers. ${ }^{32}$ The kingdom relied increasingly on these Gulf connections as a source of Jordanian employment, labour remittances, and considerable Arab foreign aid to Jordan. Jordan was viewed as a frontline state in the conflict with Israel, with some 500,000 Palestinians taking refuge in the country following the Arab-Israeli war of 1948, and then subsequent annexation of the West Bank in 1949, which almost trebled the population. ${ }^{33}$

In turn, the discovery of phosphate in Jordan in 1908 and later establishment of mining from 1935 through the TransJordan Phosphate Company grew a successful resource extractive industry for the country. 34 The Arab Potash Company was later developed in 1956 to harvest minerals in the Dead Sea, with potassium phosphate and potassic fertilizers remaining the top exports of Jordan to this day. ${ }^{35}$ As many Jordanians left to work in the Gulf, increasing numbers of migrant workers moved to Jordan, predominantly from Egypt and Southeast Asia, to fill demand for low-wage workers in domestic work, agriculture, construction, and service industries. Thus, low-skilled immigration simultaneously heightened Jordanians' status via a job-ladder effect, and foreign labour became part of the clientelist redistribution of assets to citizens. ${ }^{36}$ But by the 1980 os Jordan's economy began to struggle with low productivity and high unemployment rates. The Iranian Revolution in 1979, the Iran-Iraq War (1980-8), and later Gulf War (1990-1) upset regional oil production rates, resulting in declining labour remittances and Arab bilateral aid to Jordan. This coincided with the establishment of higher government spending by the kingdom's economic planners. Increasing shortfalls in the national budget spurred Jordan onto a greater level of borrowing. With the decline in remittances and aid, Jordan's national debt steadily rose, until by 1988 the country's debt was twice its gross domestic product (GDP).

From this point, Jordan's relationship with the International Monetary Fund (IMF) played a key part in guiding the country's trajectories, with an economic liberalization program in place since 1989.37 Then Prime Minister Zayd al-Rifaai turned to the IMF and World Bank for assistance with Jordan's debt payments in a five-year plan for economic adjustment and stabilization, including dramatically cutting government expenditures. However, in Jordan the imposition of neoliberal economic policies since the 1980 os has been accompanied by political instability and unrest. Economic adjustment programs removed a key source of welfare for the public, while simultaneously reducing government spending in major sectors. ${ }^{3}$ When the government attempted to comply with IMF guidelines, austerity plans produced violent results, with riots spreading across the country in April 1989, August 1996, and June 2018. At times, the Hashemite regime backed down to comply with protestors, at others, they proceeded apace with few concessions.

Within this context of former colonial power relations and economic instability, refugees have played a major part in Jordan's development as forms of human, financial, and symbolic capital. The country has a history as a refugee host state far before it was formalized a state independent from British control in 1946. ${ }^{39}$ Since that time, Jordan has hosted displaced people from Iraq, Yemen, Sudan, Syria, and Palestine, as some of the more significant waves of refugees. According to the UNHCR, Jordan ranked as the second-highest host to the largest number of refugees relative to national population in 2017 , where one in fourteen people was a refugee under the UNHCR's responsibility. ${ }^{\circ}$ When including Palestine refugees under UNRWA's mandate, the figures rise to one in three for Jordan.

The Jordanian government has been astute about its negotiation of international aid through refugee policy. While Syrian refugees currently account for the largest group of refugees registered with the UNHCR, Jordan also hosts over two million Palestinian refugees registered with UNRWA. The arrival of Palestinian refugees from 1948, followed by those 
who fled the Six-Day War in 1967, brought major challenges for the country. ${ }^{41}$ Many of the official camps established for Palestinian refugees became enclaves for Palestinian militia and remain severely economically deprived. Yet Palestinian refugees contributed to the country's economic development in significant ways. First, they allowed Jordan to receive large amounts of development assistance from the international community to help resettle and integrate the refugees. Second, the remittances of those Palestinians who went to look for work in Persian Gulf states also helped develop Jordan's public and private sectors. These remittances, together with foreign aid, have contributed to developing sectors of the Jordanian economy by providing start-up money for Jordanian businesses and for large state-sponsored projects.

With the Iraqi crisis, Jordan strategically increased its use of refugee hosting as an instrument of foreign policy. During the 1990 a and 200os, Jordan's sources of foreign aid decreased and its appeals for humanitarian aid centred on the "burden" of hosting thousands of Iraqi refugees. The Jordanian government was later criticized for inflating the size of the crisis and the level of need to elicit higher funding rates. For example, the government cited numbers as high as 750,000-1,000,000, while other groups concluded that no more than 100,000-200,000 Iraqis were in the country as refugees. ${ }^{42}$ Thus, by expanding or retracting refugee rights, Jordan was able to frame its ongoing ability to adequately protect and assist Iraqi refugees as dependent on contributions from the international community.

New opportunities have now emerged for Jordan as a country proximate to the Syrian conflict. 43 The Jordan Compact came about partially through the work of a Jordanian think tank, the West Asia-North Africa Institute (wANA), which submitted a White Paper to the Jordanian government on the potential contribution of Syrian refugees to the Jordanian economy. This was met by the work of Oxford economics and forced migration professors Paul Collier and Alexander Betts, who widely endorsed pathways for Syrians into the Jordanian labour market. 44 At the time, the Jordanian government was already arguing that hosting Syrian refugees has harmed the country's development outcomes. In fact, the World Bank estimated in 2016 that the Jordan government had spent over \$2.5 billion a year in direct costs for hosting Syrian refugees since the onset of the crisis: 6 per cent of GDP and 25 per cent of the government's annual revenues. ${ }^{45}$ An increasingly right-wing political climate was also sweeping across Europe, with the EU seeking ways to manage, and halt, the numbers of refugees arriving at European borders. For European states, the Jordan Compact was a way to deter Syrian refugees from migrating to Europe by improving their livelihoods in Jordan. Meanwhile, Jordan was already heavily in debt. For the Jordanian government, the compact presented an opportunity for favourable trade arrangements with the $\mathrm{EU}$ (predicted to result in increased investment), in addition to an aid package and concessional loans.

This is what Victoria Kelberer describes as "refugee rentierism" or "the phenomenon of using host status and refugee policy as primary mechanisms of international rent-seeking." 46 Through the bargaining power of refugees, Jordan was able to extract increased contributions from the international community, in much the same way as the $€ 6$ bn ( $\$ 6.8$ billion) EU-Turkey deal, in which Turkey agreed to contain refugees within its borders: allegedly as many as three million refugees. ${ }^{47}$ However, whereas Turkey agreed to receive deported migrants in exchange for money and visafree travel to the Schengen zone, the Jordanian government pledged to promote Syrian economic and social integration. Thus, in different ways, the Syrian "refugee boom" yielded new opportunities for Jordan to have access to labour markets and sources of foreign aid.

The next section turns to examine the grounded effects of the compact in more detail, arguing that extractive logics have overtaken the social concerns of refugees' and migrants' well-being. The contemporary Jordanian strategy for acquiring international aid by hosting Syrian refugees comes at the very expense of the refugees that the project is nominally supposed to support.

\section{Jordan Compact in Practice}

We have gone to the garment factories [in Khaldiyeh] linking Jordanians and Syrians with employers. Both Jordanian and Syrian women have successfully started working but then they have dropped out. Why? Because it takes at least thirty minutes to get there, one hour both ways. They need to work ten hours, minimum eight hours with two hours extra.... Mothers only want to work eight hours, but this doesn't work for the industry.

- NGO representative, Amman ${ }^{4}$

We meet with Nadine in her handicraft store several floors up in a tall, nondescript office building, above a bank in a busy street in central Amman. In contrast to the grey exterior, inside the walls are brightly coloured, shelves heaved with handmade soaps, vials of rosewater, knitted children's toys, shawls, and crocheted table decorations, delicately wrapped in exquisite packaging. Several women wearing headscarves milled around from the end of a shift, all once from far-flung cities and villages across Syria. Nadine is one of the lucky ones as the co-owner of her own business, but not without struggles and perseverance. For Syrians, owning your own business is not an easy prospect. "Work permits, work permits" is a phrase we hear incessantly as Syrians frequently tell us about the complex bureaucratic process of acquiring one. For small business-owners like Nadine, obtaining a work 
permit is often Kafka-esque, and unsuccessful. There are two routes: either pay 50,000 Jordanian dinars (US\$70,462) and partner with a local, or pay 200,000 JOD (US $\$ 281,850$ ) to be classified as an investor. 49

Nadine's story appears to be relatively characteristic of others we have heard. She initially partnered with a local businessman to set up her handicraft store in Amman, but he took advantage of her precarious status as a foreign citizen and made off with the majority of her investment and stock-something she found was of little interest to local police, who chalked off the incident as little more than unfortunate. Luckily, before the Syrian conflict, Nadine had a successful business in Damascus. Savings, family connections in Europe, NGO grants, and the partnership of a Syrian cousin enabled her to reignite the small business. Now committed to helping those affected by the war, Nadine has over one hundred Syrian women on flexible contracts (some working from home) to help produce the beautifully packaged goods so intricately placed around her store: a far cry from when she first started in 2013 with five women in a dingy office space. Some of the women are widows, others successful young professionals unable to instrumentalize their skills in Jordan, a number have husbands still fighting in the war or curtailed from working by Jordan's strict immigration rules. "We work on our own terms here," she tells us, describing how the cooperative works to combat the demands of most available employment for Syrian refugees-concerns voiced by the NGO representative in the opening quote to this section. Instead, Nadine now sells products online and on social media, and even advertises through AirBnB Experiences to help guarantee a steady stream of revenue, bulking up her retail with soap-making workshops for tourists, wealthy Ammanites, and NGO workers.

Nadine's experience speaks to just some of the myriad difficulties encountered by Syrian refugees in Jordan. Although wrapped in discourses of innovation, the Jordan Compact has been marred by failures and uneven outcomes. The compact had two major elements-the development of special economic zones or sEZs (industrial parks for manufacturing goods) and the issuing of work permits to Syrian refugees in specified sectors both in and out of the industrial export zones. ${ }^{50}$ Besides development funding, Jordan was promised access to tariff-free trade with the EU, providing it issued at least 200,000 work permits to Syrians. While work permits were made widely available to Syrians from April 2016, by February 2017 only 38,516 permits had been issued, the majority in agriculture and construction. ${ }^{51}$ The government sought to meet its quotas by formalizing work in agriculture, construction, and manufacturing. But, according to local NGOs, many of the work permits in the agricultural sector were based on Syrian workers in the country prior to the conflict.
In reality, the compact has created few if any new jobs, and instead redistributes some positions held by migrant Bangladeshis and Egyptians to Syrian refugees as preferential migrant workers, which helps meet formal targets of donors and implementing agencies. Meanwhile, although Syrian refugees are allowed to apply for work permits outside of the sEzs, they are barred from applying for some professions, such as engineering, medicine, law, teaching, driving, and hairdressing, for which they have previously been trained, but which are viewed as potentially taking opportunities from Jordanian workers. Instead, jobs are in backbreaking sectors like garment manufacture, agriculture, and construction that are of little interest to the majority of the population, many just having been through the brutality of conflict and displacement. These jobs are unregulated and are at times rife with overtime physical abuse. The hours are punishingly long (a minimum of ten-hour shifts), wages low, and safety of little concern.

Several NGOs in Jordan have taken an interest in employermatching programs to ensure more accountability of otherwise occluded business practices. However, these NGOs also hold their own work quotas-one organization I spoke with cited a "20,0000 refugees in employment scheme" - in addition to being understaffed and under-resourced..$^{52}$ The drive to reach these sorts of employment targets by contracted NGOS calls into question their ability to act as employer watchdog enforcers. While the Jordanian government has made some changes to ease the work permit process for Syrian refugees, including waiving the work permit fee and prioritizing Syrian refugees over other foreign workers, Syrians continue to face extreme restrictions to employment. Not only do Syrians in Jordan face significant barriers in accessing decent, paid work, but a future Syria is as risk of what was so often described to me by refugees and advocates as "a lost generation," unused to core professions such as medicine, engineering, and education. 53

For many Syrians, there is little advantage to formalized employment. Instead, the rigid and bureaucratic labour market has resulted in widespread informal work. For some refugees I spoke with there is fear of losing access to the UNHCR cash assistance or the chance of resettlement to a third country. "If we do lose our job we could end up without any income at all," Mohammad, a father of three pointed out, voicing the widespread concern that holding a work permit may make one ineligible for cash assistance, and thus unable to cover what a family needs to survive. ${ }^{54}$ As a result, refugees must choose between working informally at the risk of arrest and deportation or seeking unskilled work on a one-year working permit. Other refugees suggested that work permits might actually decrease their working conditions because their work permit sponsor exerts extreme controls over their mobility. ${ }^{55}$ Being reliant on precarious worker visas places 
workers in a position where they end up not voicing concerns, perhaps more exploitable and paid lesser wages-or are unaware of the labour standards that should be in place.

Some refugees prefer to remain under the radar rather than risk registering with a government they mistrust. "Sometimes authorities will make it hard for you even if you have papers," Mohammad continued. "They'll make trouble for you just because they feel like it. Nothing-paper or no paper-is really protection." Deportations of Syrians have indeed skyrocketed since 2016, with reports of more than 4,10o Syrians returned to Syria on the grounds that they pose potential security problems, including working without a permit, which is the most prominent reason for deportation in a context where workplace raids have become commonplace. ${ }^{56}$ It is not uncommon for Syrian refugees to register for work permits as protection from deportation. However, this is clearly counter to the aims of the compact, which was presented as beneficial for Syrians. Given that refugees in camps have minimal freedom of movement outside, the "opportunity" to work in factories when they have little other option is certainly coercive, and counter to the "helping refugees help themselves" motto that Betts and Collier advanced. 57

Particular challenges are felt by women in the Jordan Compact experiment, some of which were voiced by Nadine and members of her team, as they sought to ameliorate the corporate and back-breaking work structure of labour production..$^{5}$ Less than 4 per cent of formal work permits have been issued to women, while at the time of my fieldwork only 150 Syrian women were part of a cash-for-work program from Zaatari to the industrial parks. I found that the principle factor for these low take-up rates related to the location and requirements of the industry. Syrian women face gender roles and responsibilities as mothers or at times in female-headed households, which are on the rise from 25 per cent a few years ago to nearly 40 per cent in 2016.59 With employment at minimum wage (220JOD or us $\$ 310$ a month) and working conditions of little concern, it is unsurprising that efforts in targeting Syrian women to work have encountered difficulties. In another interview, a UNHCR representative said that even when they launched the "perfect" program, which provided Syrian women with child care, transportation to factories, and decent working hours and conditions, they still failed to retain workers. ${ }^{60}$ Rather, Syrian women generally prefer to work at home, or close to home for cultural and practical reasons. Many Syrian women run their own income-generating projects from home, including knitting, beauty salons, or clothes altering.

Yet, instead of supporting home-based businesses, limitations are placed on creating home-businesses that have affected Syrian women's economic autonomy. These restrictions have led to a culture of occlusion where home businesses are hidden under the radar, in fear of deportation. For example, one Syrian woman I spoke with described running a hairdressing salon (a closed-off sector) out of her home, quickly swapping bottles of shampoo for nail polish (an open sector), during a spate of police visitations. ${ }^{61}$ This case characterizes the perennial fear and at times farcical practices that Syrian refugees are forced to engage in constantly. In a country where female labour force participation is very low, 14 per cent in 2016 (compared to 22 per cent in the MENA region), and where the unemployment rate for young women (aged fifteen to twenty-four) is at 56 per cent, nearly double the rate of that of young men (29 per cent), the Jordan Compact only strengthens the gender gap across locals and refugees alike. ${ }^{62}$

What is clear from these findings is how the concerns of affected populations have been subsumed under the guise of "development." As James C. Scott famously showed, largescale authoritarian plans misfire when they fail to integrate local, practical knowledge. ${ }^{63}$ In quickstep with this classic critique of development and humanitarian work, the majority of refugees in Jordan were not actively consulted in the compact programs that affect their lives, nor were experts on the region, NGOS, and research centres in Jordan. Rather, the compact reveals a high level of donor interest in presenting Jordan as a model of reform and globalization in the MENA region in order to allow for the continued management of refugees outside of Europe ${ }^{64}$ At its core the compact aims to reduce the international migration of Syrians, but it should be recognized that migration is an essential part of people's future well-being that is actually an agent of development. ${ }^{65}$ Meanwhile, an overwhelming aid industry has grown in Jordan around Syrian refugees as major funding targets of development aid. For many service providers, there is little incentive in directly critiquing the compact when it runs in opposition to the extraction of revenue. ${ }^{66}$ The compact itself provides little incentive for Jordan to implement the much-needed reforms for overhauling the business development landscape. Instead, the Jordanian government relies largely on the quick cash from the arrangement to kickstart their economy, often at the expense of the people the project is supposed to help.

In recent years, we see a move towards instrumentalizing North/South power relations in order to facilitate new modes of extraction in migration management and containment. These relationships often have imperial dimensions, reproducing lasting colonial patterns of trade and dependency. ${ }^{67}$ Harnessing humans as resources in this way, this article has argued, is really a program of extraction for the benefit of governments and investors. Rather than creating livelihood opportunities for refugees, the Jordan Compact demonstrates a high degree of control and coercion over individuals. This is justified by some, such as the Jordanian 
government, by receiving financial support and international kudos for the future; by European governments, for the value of militating against the movement of refugees to Europe; and by others, including contracted NGOs, the economic and/or moral value of contracts associated with refugee integration provisions. Ultimately, instead of focusing on the profoundly political problems that underpin the drivers of forced migration, such as increased conflict, the compact runs the risk of abdicating global responsibility, regulating people's movement in line with value-laden interests.

\section{Conclusion}

This article has questioned whether employment programs in Jordan offer meaningful work for Syrian refugees or whether they are arrangements for extracting value. What was stark throughout my fieldwork was the many disadvantages for the compact's perceived beneficiaries. Although presented by the international community through buzzwords like innovation and self-reliance, and helping refugees help themselves, my findings indicated that Syrian refugees (and nonSyrian refugee and migrant worker populations) in Jordan all too often end up in hazardous or precarious informal work in the quest for government and organizational gain. Indeed, the ramping up of assistance operations has created thousands of jobs within the humanitarian response sector as well as numerous indirect jobs across other sectors. ${ }^{68}$ Yet while refugees are immobilized in Jordan, deprived of movement to wealthier countries with established resettlement systems, their immobility makes possible the mobility of value outside of Jordan's borders. Now, the spectacle of border-making generates a multitude of images and discursive formations that fuel anti-immigrant sentiments for European political and organizational profit. ${ }^{69}$ In the process, a range of actors can extract political, economic, and moral value while refugees' bodies stay in Jordan.

At the same time, the global visibility of arrangements like the Jordan Compact induces new policies to be taken up and embedded in different contexts. Migration studies scholars have identified a trend in asylum outsourcing and development projects as a means for states to shrink spaces of asylum and subvert international refugee law..$^{70}$ Nation states use financially struggling states to warehouse migrants and isolate them from asylum claims processes. Jordan is part of a fashion of geopolitical cooperation between wealthier former colonial states and poorer dependent ones around frontiering projects. In an age of refugee demonization, the Jordan Compact model is now being trialled for other countries as a "solution" for European countries keen to deter migrant and asylum seeker arrivals. Financing refugee hosting capacities in countries viewed as ones of transit for migrants potentially seeking refuge in Europe have spanned locations such as Ethiopia, Lebanon, Mali, Nigeria, Niger, and Senegal. This tendency signifies a new form of extractive capitalism, which taps into forms of neo-colonial domination and asymmetric relations of dependency.

\section{Notes}

1 UNHCR, "2018 Total Persons of Concern," https://data2 .unhcr.org/en/situations/syria/location/36.

2 Rawan Arar, "The New Grand Compromise: How Syrian Refugees Changed the Stakes in the Global Refugee Assistance Regime," Middle East Law and Governance 9 (2017): 298-312.

3 Turkey, Lebanon, Jordan, Iran, Pakistan, Uganda, Kenya, Ethiopia, Chad, and the Democratic Republic of Congo host the majority of the world's refugees. These statistics are obtainable from the UNHCR, "2018 Total Persons of Concern."

4 World Bank, "Jordan's Economic Outlook-April 2018," 2017, https://www.worldbank.org/en/country/jordan/ publication/economic-outlook-april-2018.

5 See, for example, Vernonique Barbelet, Jessica HagenZanker, and Dina Mansour-Ille, The Jordan Compact: Lessons Learnt and Implications for Future Refugee Compacts (London: ODI, 2018); Daniel Howden, Hannah Patchett, and Charlotte Alfred, "The Compact Experiment: Push for Refugee Jobs Confronts Reality of Jordan and Lebanon," Refugees Deeply Quarterly, December 2017, http://issues. newsdeeply.com/the-compact-experiment. For examples of scholarship that calls for field-based ethnographic work, see Heaven Crawley, "Why Jobs in Special Economic Zones Won't Solve the Problems Facing the World's Refugees," Conversation, April 6, 2017; Jennifer Gordon, "For Refugee Compact to Talk Jobs, It Must Listen to Migration Compact," Refugees Deeply, March 5, 2018, https://www. newsdeeply.com/refugees/community/2018/03/05/for-refugee-compact-to-talk-jobs-it-must-listen-to-migrationcompact; Cindy Huang, Nazanin Ash, Katelyn Gough, and Lauren Post, "Designing Refugee Compacts: Lessons from Jordan." Forced Migration Review 57 (2018): 52-4; Victoria Kelberer, "Negotiating Crisis: International Aid and Refugee Policy in Jordan," Middle East Policy 24, no. 4 (2017): 148-65; Heliodoro Temprano Arroyo, "Promoting Labor Market Integration of Refugees with Trade Preferences: Beyond the EU-Jordan Compact," European University Institute RSCAS Working Paper, 2018.

6 Heaven Crawley, "Migration: Refugee Economics," Nature 2, 544 (2017): 26-7; Gordon, "For Refugee Compact to Talk Jobs"; Kelberer, "Negotiating Crisis"; Katharina Lenner and Lewis Turner "Making Refugees Work? The Politics of Integrating Syrian Refugees into the Labor Market in Jordan," Middle East Critique 28 (2019): 65-95.

7 Sara Elizabeth Williams, "Jordan Looks to Turn Refugee Crisis into Economic Boon," IRIN News, March 
21, 2017, https://www.irinnews.org/feature/2017/03/21/ jordan-looks-turn-refugee-crisis-economic-boon.

8 Elisa Pascucci, "Refugees in the Iт Sector: Young Syrians' Economic Subjectivities and Familial Lives in Jordan," Geographical Review 109, no. 4 (2019): 580-97.

9 Rebecca Harris, “Transforming Refugees into 'Illegal Immigrants': Neoliberalism, Domestic Politics, and Syrian Refugee Employment in Jordan" (BA thesis, Brown University, 2016); Kelberer, "Negotiating Crisis"; Lenner and Turner, "Making Refugees Work?"; Katharina Lenner and Lewis Turner, "Learning from the Jordan Compact," Forced Migration Review 57 (2018): 48-51.

10 Lenner and Turner, "Making Refugees Work?"

11 Alisa Reznick, "Syrian Worker Programme Faces Hurdles in Jordan," Al Jazeera, September 23, 2016, https://www. aljazeera.com/news/2016/o9/syrian-worker-programmefaces-hurdles-jordan-160919073944811.html.

12 Julia Morris, "Power, Capital and Immigration Detention Rights: Making Networked Markets in Global Detention Governance at UNHCR," Global Networks 17 (2017): 400-22.

13 Jordanian Response Plan, 2017-19.

14 Lenner and Turner, "Making Refugees Work?"

15 Kelberer, "Negotiating Crisis."

16 Lenner and Turner, "Learning from the Jordan Compact"; Lenner and Turner "Making Refugees Work?"

17 Julia Morris, "Violence and Extraction of a Human Commodity: From Phosphate to Refugees in the Republic of Nauru," Extractive Industries and Society 6, no. 4 (2019): 1122-33, https://doi.org/10.1016/j.exis.2019.07.001.

18 Jerry K. Jacka, "Environmental Impacts of Resource Extraction in the Mineral Age," Annual Review of Anthropology 47 (2018): 61-77.

19 Alberto Acosta, "Extractivism and Neo-Extractivism: Two Sides of the Same Curse," Beyond Development: Alternative Visions from Latin America (2013): 61-86 (Quito: Rosa Luxemburg Foundation).

20 Chris Ballard and Glenn Banks, "Resource Wars: The Anthropology of Mining," Annual Review of Anthropology 32 (2003): 287-313.

21 Ruben Andersson, Illegality, Inc.: Clandestine Migration and the Business of Bordering Europe (Berkeley: University of California Press, 2014); Nicholas De Genova, "Spectacles of Migrant "Illegality': The Scene of Exclusion, the Obscene of Inclusion," Journal of Ethnic and Racial Studies 36, no. 7 (2013): 1180-98.

22 Hein de Haas, "Myths of Migration: Much of What We Think We Know Is Wrong," blog, March 29, 2017, http:// heindehaas.blogspot.com/2017/03/myths-of-migrationmuch-of-what-we.html.

23 Cecilia Menjivar, "Immigration Law beyond Borders: Externalizing and Internalizing Border Controls in an Era of Securitization," Annual Review of Law and Social Science 10 (2014): 353-69.

24 Feyzi Baban, Suzan Ilcan, and Kim Rygiel, "Syrian Refugees in Turkey: Pathways to Precarity, Differential Inclusion, and Negotiated Citizenship Rights," Journal of Ethnic and Migration Studies 43, no. 1 (2017): 41-57.

25 This is not to present this scholarship as any less entangled in the dynamics of power that define academic research, but to underline the point that practitioners are also caught up in the political economy of value, while exposing important realities.

26 Tania Golash-Boza, “The Immigration Industrial Complex: Why We Enforce Immigration Policies Destined to Fail," Sociology Compass 3, no. 2 (2009): 295-309.

27 Thomas Gammeltoft-Hansen and Ninna Nyberg Sørensen, eds., The Migration Industry and the Commercialization of International Migration (London: Routledge, 2013).

28 Anne Peters and Pete Moore, "Beyond Boom and Bust: Eternal Rents, Durable Authoritarianism, and Institutional Adaptation in the Hashemite Kingdom of Jordan," Studies in Comparative International Development 44 (2009): 256-85.

29 Kelberer, "Negotiating Crisis."

30 Charlie Dunmore, "UnHCR's Grandi Hails Jordan's Job Scheme for Syrian Refugees," UNHCR, February 12, 2018, http://www.unhcr.org/en-us/news/ latest/2018/2/5a81bd504/unhcrs-grandi-hails-jordans-jobscheme-syrian-refugees.html.

31 Timothy J. Piro, The Political Economy of Market Reform in Jordan (Lanham, MD: Rowman \& Littlefield, 1998).

32 Curtis D. Ryan, "Peace, Bread and Riots: Jordan and the International Monetary Fund," Middle East Policy Council 6, no. 2 (1998): 54-66.

33 Peters and Moore, "Beyond Boom and Bust."

34 Awwad Titi, Rami Al Rawashdeh, and Khalid Al Tarawneh, "Peak Phosphate in Jordan," International Journal of Mining and Mineral Engineering 10, no. 1 (2019): 27-50.

35 For a discussion of the intersections of mineral and migrant resource extractive industries, see Morris, "Violence and Extraction of a Human Commodity."

36 Françoise De Bel-Air, "Migration Profile: Jordan," Migration Policy Centre Policy Brief, European University Institute, 2016, 6.

37 Jane Harrigan, Hamed El-Said, and Chengang Wang, "The IMF and the World Bank in Jordan: A Case of Over Optimism and Elusive Growth," Review of International Organizations 1 (2006): 263-92.

38 Anne Marie Baylouny, "Militarizing Welfare: Neo-liberalism and Jordanian Policy," Middle East Journal 62, no. 2 (2008): 277-303.

39 Kelberer, "Negotiating Crisis."

40 Operational Portal, "UNHCR Jordan Factsheet February 2018," https://data2.unhcr.org/en/documents/details/62241.

41 Geraldine Chatelard, "Jordan: A Refugee Haven," Migration Policy Institute, August 31, 2010, https://www.migrationpolicy.org/article/jordan-refugee-haven.

42 Kelberer, "Negotiating Crisis."

43 Jordan has experienced economic benefits from the Syrian conflict; however, the proximity of the conflict has also had negative impacts on the country. See Elizabeth 
Parker-Magyar, "Jordanians See More to Worry About in Their Economy Than Syrian Refugees," Lawfare, September 15, 2019. https://www.lawfareblog.com/jordanians-seemore-worry-about-their-economy-syrian-refugees.

44 Alexander Betts and Paul Collier, Refuge: Rethinking Refugee Policy in a Changing World (Oxford: Oxford University Press, 2017). Collier himself was an advisor at the wANA Institute and former director of the Development Research Group of the World Bank.

45 World Bank, "The Economic Effects of War and Peace," Middle East and North Africa Quarterly Economic Brief 6 (January 2016).

46 Kelberer, "Negotiating Crisis," 157.

47 Deutsche Welle, "The EU-Turkey Refugee Agreement: A Review," 2018, https://www.dw.com/en/the-euturkey-refugee-agreement-a-review/a-43028295.

48 Interview with NGO representative contracted for refugee integration work in Jordan, March 19, 2018, Amman.

49 Jordan INGo Forum, “The Work Permit Maze," 2016, https:// data2.unhcr.org/en/documents/download/53371.

50 Jordan has a history of zonal development policies, which have offered duty-free and quota-free access to Jordanian companies for international markets. See Shamel Azmeh, "Labour in Global Production Networks: Workers in the Qualifying Industrial Zones (QIZs) of Egypt and Jordan," Global Networks 14, no. 4 (2014): 495-513.

51 Sara Elizabeth Williams, "Jordan Looks to Turn Refugee Crisis into Economic Boon," IRIN News, March 21, 2017.

52 Interview with NGO practitioner contracted for refugee integration work, March 10, 2018, Amman.

53 Informal chats with refugees and NGo practitioners, March 2018, Amman.

54 Interview with Syrian refugee, March 18, 2018, Amman.

55 Informal chats with refugees and NGO practitioners, March 2018, Amman.

56 Human Rights Watch, "I Have No Idea Why They Sent Us Back' Jordanian Deportations and Expulsions of Syrian Refugees," October 2, 2017, https://www.hrw.org/ report/2017/10/02/i-have-no-idea-why-they-sent-us-back/ jordanian-deportations-and-expulsions-syrian; Petra Molnar, "Discretion to Deport: Intersections between Health and Detention of Syrian Refugees in Jordan," Refuge 33, no. 2 (2017): 18-31.

57 Alexander Betts and Paul Collier, "Help Refugees Help Themselves: Let Displaced Syrians Join the Labor Market," Foreign Affairs, November/December 2015. https:// www.foreignaffairs.com/articles/levant/2015-10-20/ help-refugees-help-themselves.

58 Laura Buffoni, "The Jordan Compact Could Work Better if We Listen to Women Refugees,' Refugees Deeply, May 28, 2018; Camille Dupire, "Syrian Refugee Women Still Struggle to Access Employment," Jordan Times, September 6, 2018, http://www.jordantimes.com/news/local/syrian-refugeewomen-still-struggle-access-employment-\%E2\%80\%94- report; Saira Shackle, "Safe Spaces: As the Syrian Crisis Forces Women to Fend for Themselves, Female Refugees in Jordan Are Learning to Cope," World Policy Journal 35, no. 1 (2018): 99-106.

59 CARE International, On Her Own: Women Forced to Flee from Syria Are Shouldering Increased Responsibility as They Struggle to Survive, 2016,

60 Interview with UNHCR representative, March 20, 2018, Amman.

61 Interview with Syrian refugee, March 10, 2018, Amman.

62 Susan Razzaz, "A Challenging Market Becomes More Challenging: Jordanian Workers, Migrant Workers and Refugees in the Jordanian Labour Market," International Labor Organization, 2017.

63 James C. Scott, Seeing Like a State: How Certain Schemes to Improve the Human Condition Have Failed (New Haven, Ст: Yale University Press, 1999).

64 For discussions of the ways in which Syrian refugees have pushed back against contentious policies, see Rana Khoury, "Aiding Activism? Humanitarianisms' Impacts on Mobilized Syrian Refugees in Jordan," Middle East Law and Governance 9, no. 3 (2017): 267-81.

65 Oliver Bakewell, “Keeping Them in Their Place': The Ambivalent Relationship between Development and Migration in Africa," Third World Quarterly 29, no. 7 (2008): 1341-58.

66 As international investments have begun to decline, however, discussions have moved to the possibility of initiating formal returns projects for Syrian refugees in Jordan. See Julia Morris, "The Politics of Return from Jordan to Syria," Forced Migration Review 62 (2019): 31-3.

67 Julia Morris, "Violence and Extraction of a Human Commodity: From Phosphate to Refugees in the Republic of Nauru," Extractive Industries and Society 6, no. 4 (November 2019): 1122-33, https://doi.org/10.1016/j.exis.2019.07.001.

68 WANA Institute, "Executive Summary: The Syrian Refugee Crisis in Jordan and Its Impact on the Jordanian Economy," 2019, https://www.mercycorps.org/sites/default/files/1_ SyrianRefugeeCrisisImpactJordanEconomyExecSummary .pdf.

69 Sandro Mezzadra and Brett Neilson, Border as Method, or, The Multiplication of Labor (Durham, NC: Duke University Press, 2013).

70 Alice Bloch and Liza Schuster, "At the Extremes of Exclusion: Deportation, Detention and Dispersal," Ethnic and Racial Studies 28, no. 3 (2005): 491-512; Andonea Dickson, "Distancing Asylum Seekers from the State: Australia's Evolving Political Geography of Immigration and Border Control," Australian Geographer 46, no. 4 (2015): 437-54.

Julia Morris is assistant professor of international studies at the University of North Carolina Wilmington. She can be reached atmorrisjc@uncw.edu. 